\title{
СТРУКТУРНА МОДЕЛЬ КОНСУЛЬТУВАННЯ СІМ’ї В РОБОТІ МЕДИЧНОЇ СЕСТРИ
}

\author{
О. І. Брик \\ ДВНЗ «Тернопільський державний медичний університет \\ імені І. Я. Горбачевського МОЗ Украӥни"
}

Розглянуто сутність структурної моделі сімейного консультування. Визначено особливості реалізації цієї моделі з метою визначення можливостей її використання у професійній діяльності медичної сестри.

\section{STRUCTURAL MODEL OF THE FAMILY COUNSELING IN THE WORK OF A NURSE}

\author{
O. I. Bryk
}

\section{Horbachevsky Ternopil State Medical University}

The essence of the structural model of family counseling is considered. The peculiarities of realization of this model with the purpose of determination of possibilities of its use in professional activity of the nurse are determined.

Вступ. Важливим аспектом у роботі медичної сестри євзаємодія не лише з хворими пацієнтами, ай їхніми рідними, що передбачає використання різних моделей консультування сім'і. Однією з таких моделей науковці визначають структурну, в якій сім'я розглядається як осередок для впливу, в якому на межі балансують стабільність і зміни, закритість і відкритість тощо. Судження, яке не викликає сумніву у фахівців медицини, часто в структурній моделі передбачає наявність суперечливих і помилкових поглядів членів сім'ї на деякі медичні проблеми, в результаті чого можуть виникати конфлікти. Діючи разом, члени сім'ї будуть створювати сімейну систему, котра, в свою чергу, об'єднана з іншими суспільними системами, в тому числі й з тією, яка надає медичну допомогу одному з їі членів. Із цих досить очевидних суджень випливають основні поняття структурної моделі: структура сім'і, субсистеми сім'ї, границі структури.

Основна частина. Проблему вдосконалення професійної підготовки майбутніх медичних сестер визначають предметом наукових розвідок сучасні дослідники [1]. Важливу роль у медичній допомозі пацієнтам відводять їхнім сім'ям, про що зазначають лікарі та психологи [2, 3]. Науковці стверджують, що структуру сім'ї «утворює певна сітка вимог і функцій,

() О. І. Брик, 2018 котра формує способи взаємодії в сім'і» [2]. Це поведінка, що постійно повторюється і піддається прогнозу, дає можливість оцінювати, наскільки успішно функціонує сім'я. Субсистемами сім'і можуть бути подружні пари, батьки, діти.

Знаючи специфіку функціонування цих субсистем, медична сестра матиме змогу налагодити оптимальні стосунки з пацієнтами та членами їхніх сімей, представниками різних поколінь. Оскільки в нову сім'ю приносяться правила батьківських сімей, подружжя, яке залишається матеріально, просторово, психічно залежним від батьківської сім'ї, переживає великі труднощі пристосування і значно частіше відкидає, ніж приймає, ті ролі, котрі йому необхідно засвоїти. I хоча після укладання шлюбу молоде подружжя намагається копіювати традиційні ролі, проте це не завжди приводить до успіху. Завдання пари - відшукати власну систему ролей не лише для міжособистісної взаємодії, а й для спілкування з власними дітьми, батьками. Особливого значення це набуває, коли комусь із сім'ї доводиться звертатися у заклади медичної допомоги, де одним із посередників у міжособистісній взаємодії виступає медична сестра.

Субсистема батьків з'являється з трансформацією подружньої пари після появи в сім'ї дитини. Кожен із подружжя має своє уявлення про батьківство і мате- 
ринство. І часто ще в пологовому будинку медичні працівники надають певні консультативні рекомендації щодо створення оптимальних умов для розвитку субсистеми батьків та їі інтеграції із субсистемою дітей. Адже залежно від прийнятих сімейних цінностей, інколи в центр уваги беруться переваги дітей, а інколи потреби дитини (дітей), що вимагає їх узгодження, основаного на авторитеті сімейної ієрархії, в котрій діти не будуть рівними з батьками. Через субсистему батьків вони набувають навичок відчувати авторитет і вчаться співпрацювати в ситуації нерівних авторитетів. Тому саме ці ознаки взаємодії субсистем доцільно враховувати в роботі медичної сестри.

Відомо, що субсистема батьків змінюється та пристосовується до дитини залежно від її вікового періоду, тому для консультування сім'і від медичної сестри вимагається глибоке розуміння вікової та педагогічної психології. Крім того, субсистема батьків повинна враховувати потреби всіх дітей в сім'ї. На основі визначення взаємодії між субсистемами батьків і дітей в окремих сім'ях, медична сестра матиме змогу оптимізувати надання консультативної допомоги як пацієнтам, так і членам їхніх сімей.

Призначення субсистеми дітей - надати дитині можливість бути лише дитиною (ні сином, ні дочкою, ні внуком чи внучкою) і вивчати взаємовідносини ровесників, виховувати вміння погодження та пристосування. Наприклад, психологи [2] називають таку підсистему соціальною лабораторією, де можна експериментально спілкуватися без особливої відповідальності, компетентності та соромлячих обставин дорослих. Виокремлення субсистем дає можливість чітко визначити їх внутрішні та зовнішні зв'язки, а ці зв'язки характеризують структуру сім'і так само, як і поняття границь. Вони в структурній моделі окреслюють правила, які визначають рівень і рід дозволених контактів. Відповідно поняття границі досить близьке до поняття норми спілкування, тільки границя має більш чіткий вияв забороненої поведінки.

Науковці виокремлюють 3 види границь:

1. Чіткі границі - найбільш бажаний варіант між сімейними субсистемами. Завдяки таким границям члени сім'ї підтримують і опікують один одного (зокрема, під час хвороби когось із членів сім'і). Разом із тим, допускається певна автономія, тому забезпечується рівновага між свободою і контролем. Чіткі границі також покращують комунікацію між субсистемами і спрощують погодження і пристосування, оскільки багато речей завдяки таким границям наперед відомі.
Чіткі границі дають можливість батькам і дітям відчути взаємозалежність, що не заважає виявленню їхньої індивідуальності.

2. Ригідні границі ізолюють членів сім'ї один від одного і навіть від суспільства. В сім'і з ригідними границями її члени автономні, але сім'ї складно функціонувати, бо не відбувається погодження і пристосування. Діти набувають навичок боротьби за себе, але не виробляють навичок погодження. Спілкування між субсистемами в сім'ї з ригідними границями кволе. Лише інтенсивна криза, екстремальний стрес (якими може бути хвороба когось із дітей чи батьків) об'єднують сім'ю, щоб допомогти комусь із її членів. Слова, характерні для сім'і з ригідними границями: не заважай, у мене свої турботи, займись своїми справами. Медичній сестрі важливо знати, що саме члени сімей з ригідними границями найчастіше шукають допомоги поза сім'єю. У такій ситуації саме медична сестра може виконувати роль авторитетного співрозмовника і консультанта.

3. Дифузні границі є протилежними ригідним. У сім'ях із дифузними границями кожний член постійно турбується про інших і постійно намагається, прагне пропонувати і надавати допомогу. В таких сім'ях нечітко визначені функції субсистем, через надмірне пристосування і погодження. Деяких батьків це влаштовує, але при цьому розвиток дітей сповільнюється. В сім'ях із дифузними границями субсистема пари немов би зникає, розчиняючись у батьківській субсистемі. Внаслідок цього діти впевнені в своїх батьках, але не впевнені в собі. Окрім цього, на думку психологів [3], діти дезорієнтуються у світі почуттів, не знають, які з них власні, а які - відгук батьківських. Тому їм складно встановити взаємовідносини поза сім'єю, нелегко створити і власну сім'ю. Особливо тоді (а це трапляється майже завжди), коли не отримують більш інтенсивної підтримки, ніж вона була в батьківській сім'ї. Відтак у роботі медичної сестри необхідно враховувати специфіку дифузних границь у таких сім'ях при переконанні пацієнтів у необхідності тих чи інших лікувальних процедур та маніпуляцій.

Окрім цих основних понять, у структурній моделі важливе місце посідають зміни сім'ї в часовому просторі. Тут виділяються так звані точки переходу, в яких змінюється структура сім'і. Ці точки такі: шлюб, народження дітей, початок навчання дітей в школі, період юності дитини, покидання дітьми батьківської домівки. В країнах західної культури ці перехідні точки за умови нормального розвитку сім'ї $є$ симптомами 
очікуваної кризи. Поряд з очікуваною кризою може траплятися і неочікувана криза, яка також може змінювати структуру сім'ї. Це раптова хвороба, втрата соціального статусу (арешт, безробіття), поява нових елементів у структурі сім'ї (приєднання до сім'і бабусі, дідуся, прийом вихованця, розлучення, смерть). Психологи вважають, що найефективніше впливати на сім'ю під час кризи, особливо глибокої.

Викладені ідеї дають можливість охарактеризувати функціонально успішну сім'ю. Прихильники структурної моделі стверджують, що така сім'я необов'язково повинна мати традиційну структуру: батько, мама і дитина. Склад зразкової сім'ї може бути і таким: вітчим, мама і діти або ж навіть мати (тато) і дитина. Вирішальним фактором при створенні функціонально успішної сім'ї $є$ сформованість відповідних субсистем і встановлення границь.

Успіх зразкової сім'ї прихований в здатності змінювати, вдосконалювати, перебудовувати структуру сім'ї з урахуванням нових обставин та віку її членів. Зразкова сім'я - це орієнтир, до якого повинен прагнути фахівець, який консультує сім'ю. У зразковій сім'ї взаємодія має стабільний характер і зміна ії структури відбувається плавно, а в проблемній - навпаки, що необхідно враховувати медичним сестрам у консультативній роботі з сім'ями.

Консультування сім'ї повинно пройти три фази. На першій фазі медична сестра займає позицію лідера, водночас оберігаючи автономію сім'ї та керуючись етичними принципами їі членів. Це процес, під час якого сім'я визнає авторитет медичного працівника, а він - цінності сім'ї і також пристосовується до сти-

\section{СПИСОК ЛІТЕРАТУРИ}

1. Мельничук І. М. Теоретичні основи професійної підготовки фахівців медсестринства / І. М. Мельничук // Науковий вісник Чернівецького університету. - 2015. Вип. 749. - С. 90-98. лю сім'ї. Наприклад, приймає іï ієрархію (це можна продемонструвати, почавши розмову з питання до батьків, а не дітей).

Друга фаза - вивчення структури сім'ї, спостерігаючи взаємодію між їі членами (наприклад, попросити батьків висловити власну точку зору щодо виховання у дітей навичок здоров'язбереження). Висловлювані думки можуть відповідати або суперечити вчинкам, за якими спостерігає лікар чи медична сестра. Так, батько може стверджувати, що завжди підтримує авторитет матері, хоча фіксується «коаліція» батька і дитини, дифузні чи ригідні границі в батьківській субсистемі.

За вивченням сімейної структури прямує третя фаза консультування сім'ї - трансформація цієї структури. Наприклад, медична сестра може з'ясувати зв'язок оцінок ситуації в сім'ї, висловлених кожним їі членом, поєднати ці оцінки між собою і показати сім'ї можливу інтерпретацію її структури, наголошуючи при цьому на лікувальному впливі позитивних емоцій на здоров'я пацієнтів.

Висновки. Підсумовуючи ознаки структурної моделі консультування в сім'ї можна відзначити, що вона враховує можливість оптимізації взаємодії медичної сестри з пацієнтами та членами їхніх сімей. Відсутність спеціальних, характерних лише для цієї моделі засобів впливу на сім'ю можна оцінювати як ії перевагу. Знаючи особливості вікового розвитку особистості, специфіку комунікативної взаємодії та стилів спілкування, медична сестра матиме змогу надавати консультативну допомогу сім'ї з метою покращення лікувального ефекту.

2. Шерман Р. Структурированные техники семейной и супружеской терапии / Р. Шерман, Н. Фредман. М., 1997. - 347 c.

3. Эйдемиллер Э. Г. Психология и психотерапия семьи / Э. Г. Эйдемиллер, В. В. Юстицкис. - СПб. : Питер, 1999. - 487 с. 